\title{
Dois Diabos na Periferia
}

\section{Maria Cecilia Marks ${ }^{1}$}

\begin{abstract}
The aim of this article is to analyze the representation of the devil in the novel The Brothers Karamazov, by Fyodor Dostoevsky, and in the short story A Igreja do Diabo, by Machado de Assis. The analysis is based on the tragedy of Faust, by Johann Wolfgang von Goethe, the origin of a tradition that relates to the demonic insatiability of modern man. Aspects of their historical contexts reflected in the works are also pointed as well as differences and similarities between the experiences of heroes when it comes to good and evil. Although universal, this theme reaches peculiar representations to the authors analyzed in this study, by virtue of style and creativity of each and also their various historical and cultural conditions.
\end{abstract}

Keywords: Machado de Assis; Dostoevsky; devil representation; modernity; Bakhtin.

Resumo: O objetivo deste artigo é analisar comparativamente a representação do demônio no romance Os Irmãos Karamázov, de Fiódor Dostoiévski, e no conto A Igreja do Diabo, de Machado de Assis. A análise tem por base a tragédia Fausto, de Johann Wolfgang von Goethe, origem de toda uma tradição que relaciona o demoníaco à insaciabilidade do homem moderno. Aspectos dos respectivos contextos históricos refletidos nas obras também são apontados, assim como diferenças e aproximações entre as experiências dos heróis no que tange ao bem e ao mal. Embora universal, tal temática alcança representações peculiares nos autores em estudo, em virtude do estilo e da inventividade de cada um deles e também das condições históricas e culturais diversas.

Palavras-chave: Machado de Assis; Dostoiévski; representação do demônio; modernidade; Bakhtin.

\section{Introdução}

Para analisar comparativamente a representação do demônio no conto "A Igreja do Diabo", de Machado de Assis, e no romance Os Irmãos Karamázov, de Fiódor Dostoiévski, partimos das ideias de Goethe, sobretudo na tragédia Fausto I. Utilizamos também a teoria da carnavalização na literatura proposta por Mikhail Bakhtin, que a desenvolveu tomando por base o papel catártico e transformador desempenhado pela festa popular profana do Carnaval, desde a Antiguidade até o Renascimento, e o processo de transposição dessa manifestação para a linguagem literária.

\footnotetext{
${ }^{1}$ Mestre em Teoria Literária e Literatura Comparada pela Universidade de São Paulo e doutoranda pela mesma instituição. Endereço eletrônico: ceciliamarks@usp.br.
} 
Chamaremos literatura carnavalizada à literatura que, direta ou indiretamente, através de diversos elos mediadores, sofreu a influência de diferentes modalidades de folclore carnavalesco (antigo ou medieval). Todo o campo do sério-cômico constitui o primeiro exemplo desse tipo de literatura. (Bakhtin, 2010a, p. 122; grifo do autor)

O conto "A Igreja do Diabo" foi publicado originalmente no volume Histórias sem Data, de 1884. O livro faz parte da fase madura do autor, do considerado período realista de Machado de Assis, que se inicia com Memórias Póstumas de Brás Cubas, de 1881.

Publicado em 1880, Os Irmãos Karamázov é o último romance de Dostoiévski. Portanto, os dois escritores chegaram a ser contemporâneos e os trabalhos em foco foram publicados na mesma época, não obstante a distância geográfica e cultural existente entre as realidades em que Machado e Dostoiévski construíram suas obras.

Pode-se afirmar, com enorme probabilidade de acerto, que Dostoiévski jamais teve contato com a obra de Machado de Assis. Este, por sua vez, citou o nome do escritor russo, de passagem, pelo menos uma vez. Trata-se de crônica publicada em $A$ Semana, com data de 16 de dezembro de 1894, sem título, em que Machado começa comentando o suposto suicídio de uma bailarina chamada Labushka, amante do imperador russo morto - "Foi telegramma o que li? Foi alguma pagina de Dostoiewsky?" (Assis, 1946, p. 265) -, e acaba falando de problemas brasileiros da época. Isso não significa que Dostoiévski represente uma influência para Machado. Já Goethe foi, certamente, uma referência para ambos.

Quais são, então, as aproximações que podemos identificar nas representações do demônio feitas por Machado de Assis e Dostoiévski? Como se constituem esses caracteres e a narrativa? De que recursos se valem os autores para representar a realidade e a figura demoníaca? Há consonâncias com o conceito bakhtiniano de carnavalização? Eis algumas questões a investigar neste ensaio.

“A Igreja do Diabo" é o primeiro dos 18 contos de Histórias sem Data, título que reforça a atemporalidade dos temas, sua perenidade e independência com relação ao momento histórico e até à realidade local, embora tais assuntos, sempre presentes, mudem de roupagem e/ou de abordagem ao longo do tempo, de acordo com a época, a cultura, o país. 
Dostoiévski foi um célebre leitor de Goethe, este fartamente citado em suas obras, assim como nas de Machado de Assis. Ainda que, segundo Bakhtin, Dostoiévski contraponha-se ao conceito goetheano de formação - em que "no centro do romance está a questão da formação do indivíduo, do desenvolvimento de suas potencialidades sob as condições históricas dadas" (Mazzari, 1999, p. 67) -, a obra do escritor russo é emblemática no que se refere ao "universalmente humano", conforme defendia o alemão em seu conceito de Weltliteratur, ou Literatura Universal. Expoente do romance ideológico - entenda-se no sentido de ideias, e não de ideologias -, Dostoiévski superou todos os seus contemporâneos ao expressar os limites da condição humana por meio da arte literária. De acordo com Bakhtin, Dostoiévski foi pioneiro na percepção de um mundo que, já naquele momento, vivia um processo de fragmentação de ideias, valores, crenças, ideologias; ele "percebia a profunda ambivalência e a plurivalência de cada fenômeno (...) contíguos e contraditórios, consonantes mas imiscíveis" (Bakhtin, 2010a, p. 34). Foi pela observação do diálogo infinito de consciências que Bakhtin desenvolveu a sua teoria do romance polifônico em Dostoiévski.

Dostoiévski tinha o dom genial de auscultar o diálogo de sua época, ou, em termos mais precisos, auscultar a sua época como um grande diálogo, de captar nela não só vozes isoladas mas antes de tudo as relações dialógicas entre as vozes, a interação dialógica entre elas. (Bakhtin, 2010a, p. 100; grifos do autor)

Para Bakhtin, o dialogismo é uma das principais características do gênero romanesco da literatura artística, em que o autor é capaz de impregnar o texto com as diferentes línguas faladas na sociedade, sejam elas jargões de época, de profissões, de grupos, sejam gêneros intercalados à narrativa ou a própria língua culta, abrigando, enfim, em sua linguagem, o plurilinguismo que reflete o mundo real, em todas as suas nuances e camadas da expressão verbal e ideológica, literárias e extraliterárias e em permanente transformação.

Já o recurso da parodização, em essência dialógico, uma vez que é indispensável haver um objeto parodiado para que a expressão paródica se realize, desnuda o que é oficial, canônico, unívoco de uma perspectiva oblíqua, que desconstrói dogmas e normas por meio da linguagem. "O parodiar é a criação do duplo destronante, do mesmo 'mundo às avessas"” (Bakhtin, 2010a, p. 145). 
Em Os Irmãos Karamázov, a figura do duplo desempenha papel preponderante, seja ela personificada no demônio ou exercida também por outros personagens. O duplo lança o olhar do outro sob a perspectiva do eu, é aquilo que o protagonista vê de si refletido no outro ou nele projeta. "Na relação dialógica eu não posso passar sem o outro, que me espia, me julga e me completa" (Bezerra, 2008, p. 249). Na tentativa de precisar a duplicidade em Dostoiévski, Paulo Bezerra assim expõe:

Logo, a duplicidade é aquele estado de uma consciência na qual se alojam, convivem e dialogam coisas às vezes até diametralmente opostas ou antagônicas, pondo a consciência do protagonista no movimento pendular entre aceitação e/ou recusa à consciência e ao julgamento do outro, numa atitude às vezes desesperada para afirmar a própria consciência. (...) Assim, a duplicidade radica no pavor do homem diante da vida e se manifesta em formas de cisão da consciência. A duplicidade enreda o homem numa teia de contradições de tal ordem que ele, ao ver-se diante de problemas que reclamam solução, não consegue tomar uma decisão firme e unívoca porque, quando vislumbra uma saída, logo esbarra em tantas saídas "contra" quanto em saídas "a favor". E isto vai das questões aparentemente mais simples às mais complexas, como a existência ou inexistência de Deus (Bezerra, in Dostoievski, 2011, p. 240).

Com esse suporte teórico, passamos a analisar comparativamente o conto "A Igreja do Diabo", de Machado de Assis, com o capítulo IX do livro XI do romance $O s$ Irmãos Karamázov - "O diabo. O pesadelo de Ivan Fiódorovitch”.

\section{Entre Deus e o diabo}

Tema universal e atemporal, a luta entre o bem e o mal, entre o poder de Deus e o do diabo, perpassa a alma e a razão humanas, integrando aquele rol de "coisas que não são especialmente do dia, ou de um certo dia" (Assis, 1994, p. 2), conforme adverte Machado de Assis na abertura de Histórias sem Data. A seguir, serão apontadas relações entre as obras e recursos empregados pelos autores para representar o demônio e contextualizá-lo nos limites da realidade.

O conto "A Igreja do Diabo", apesar de não ser muito extenso, divide-se em quatro capítulos. As partes organizam-se conforme o desenrolar do enredo, o que o reveste de uma lógica e de um encadeamento que provocam no leitor o princípio de realidade, mesmo sendo um episódio improvável. 
Apesar de o elemento fantástico estar presente em narrações nas quais o diabo seja um personagem, esse elemento promove a aproximação com o leitor na medida em que se reflete em crenças arraigadas, provenientes de toda a tradição religiosa judaico-cristã, e em arquétipos da civilização que determinam o bem e o mal como conceitos que se contrapõem.

Ao referir-se, na frase de abertura da narrativa, à existência de um manuscrito - "Conta um velho manuscrito beneditino que o Diabo, em certo dia, teve a ideia de fundar uma igreja" (Assis, 1994, p. 2) -, Machado de Assis utiliza mais um recurso de verossimilhança, remetendo o leitor a uma suposta fonte fidedigna da história narrada.

$\mathrm{Na}$ estrutura do conto, primeiro é apresentada a ideia "mirífica" do diabo de fundar uma igreja, a fim de formalizar a sua existência errante e deixar de viver "dos remanescentes divinos, dos descuidos e obséquios humanos" (Assis, 1994, p. 2). Depois, a conversa com Deus, para que este não o acuse de traiçoeiro, de "dissimulação". Em seguida, no terceiro capítulo, mãos à obra, o diabo parte para o empreendimento de conquistar e trazer para a sua igreja as virtudes, transmutando-as segundo a sua doutrina. Na conclusão, o diabo logrado descobre que seus fiéis estão praticando as virtudes de outrora. "É a eterna contradição humana", esclarece Deus ao demônio frustrado.

\section{Um diabo capitalista}

O capítulo II de "A Igreja do Diabo" - "Entre Deus e o Diabo" - é uma referência explícita ao "Prólogo no Céu", terceiro texto introdutório do Fausto I. Entretanto, pode-se interpretá-lo como uma réplica parodiada de Deus, por parte de um já derrotado Mefistófeles, devido ao insucesso com Fausto. A ambientação é semelhante: lá estão presentes os anjos e seu canto celeste, Deus e o diabo. A menção a Fausto aparece na primeira frase emitida pelo diabo, em resposta ao questionamento de Deus sobre o que tencionava ele ali: "Não venho pelo vosso servo Fausto, respondeu o Diabo rindo, mas por todos os Faustos do século e dos séculos" (Assis, 1994, p. 3). Note-se que o riso, associado secularmente ao diabo, também é mencionado no "Prólogo no Céu", mas em contraponto, lembrando que Deus não é afeito ao hábito de rir, conforme afirma o demônio:

Perdão, não sei fazer fraseado estético, Embora de mim zombe a roda toda aqui; 
Far-te-ia rir, decerto, o meu patético,

Se o rir fosse hábito ainda para ti. (Goethe, 2010, p. 51)

Ao se propor a fundar uma igreja e "congregar, em suma, as multidões ao pé de si" (Assis, 1994, p. 5), o diabo machadiano passa do particular para o geral, mostrando-se mais pragmático do que aquele apresentado por Goethe, cuja aposta limitava-se a Fausto.

Que apostais? perdereis o camarada;

Se o permitirdes, tenho em mira

Levá-lo pela minha estrada! (Goethe, 2007, p. 53-54)

Em Dostoiévski, o demônio também adota critérios rigorosos para a escolha de suas "vítimas", conforme se observa nesta resposta ao seguinte questionamento de Ivan Karamázov:

- Palhaço! Alguma vez tentaste ao menos um desses que comem gafanhotos, que passam dezessete anos a fio orando no deserto nu, mofando?

- Meu caro, foi só isso o que fiz. Haverás de esquecer o mundo inteiro e os mundos, mas aderirás a um deles porque o brilhante é muito precioso; uma alma como essa às vezes vale uma constelação inteira é que nós temos nossa aritmética. (Dostoiévski, 2008, p. 836)

A obra demoníaca a ser empreendida pelo diabo machadiano é voltada às massas, a "todos os Faustos do século e dos séculos", e se institui como um negócio religioso, nos moldes mercantis e capitalistas, a competir no mercado das almas: "Embora os seus lucros fossem contínuos e grandes, sentia-se humilhado com o papel avulso que exercia desde séculos, sem organização, sem regras, sem cânones, sem ritual, sem nada" (Assis, 1994, p. 2).

Com a nova oportunidade identificada pelo demônio, ele acredita que “(...) o céu fique semelhante a uma casa vazia, por causa do preço, que é alto. Vou edificar uma hospedaria barata (...)" (Assis, 1994, p. 3), diz ele a Deus. Muitas outras menções do diabo machadiano remetem ao valor material e monetário, mas, nos limites desse trabalho, o importante é salientar que, para o diabo representado no conto de Machado de Assis, a fundação de uma igreja é “(...) o meio eficaz de combater as outras religiões, e destruí-las de uma vez” (Assis, 1994, p. 2). "É tempo de obter a vitória final e completa" (Assis, 1994, p. 3). 
O projeto do demônio dispõe de todo o aparato requerido para se tornar um credo merecedor da fé dos homens, ou seja, oferece ritos e cânones equivalentes aos que outras igrejas impõem. Nesse particular, o conto machadiano configura-se em paródia da realidade religiosa desde o paradoxal título até ao enumerar os acessórios necessários para a prática ritual: “- Vá, pois, uma igreja, concluiu ele. Escritura contra Escritura, breviário contra breviário. Terei a minha missa, com vinho e pão à farta, as minhas prédicas, bulas, novenas e todo o demais aparelho eclesiástico" (Assis, 1994, p. 2).

Assim, o conto ajusta-se com muita precisão à categoria carnavalesca da profanação, conforme a teoria bakhtiniana. Como um sacrilégio, instala na cena religiosa, com todo o seu aparato ritual, o seu inverso, o demônio, configurando-se numa representação da "vida às avessas" (Bakhtin, 2010a, p. 140).

No quesito ordem, decerto não é à toa que Machado de Assis coloca como referência para o diabo a ordem dos beneditinos. Duas vezes é citado o tal manuscrito e uma vez a cogula, vestimenta característica daqueles monges, que o diabo escolhe para usar - "como hábito de boa fama" (Assis, 1994, p. 4), mais uma expressão com alto teor paródico. A Congregação de São Bento foi fundada por Bento de Núrsia, santo que consta ter tido duros embates com o demônio. Bento de Núrsia pontificou normas estritas para a vida monástica por meio da Regula Benedicti. Escrito no século VI, esse documento serviu de inspiração para muitas outras ordens religiosas que se estabeleceram posteriormente. A Regra expõe, de forma contundente e detalhada em seus 73 capítulos $^{2}$, como os seguidores da ordem beneditina devem se comportar e agir. Ora et labora é o princípio fundamental da irmandade, que mantém uma rotina de oração e trabalho, uma revolução em relação à herança romana, "que tinha como ideal de vida o ócio pessoal do homem culto, o otium" (Rouche, 2009, p. 522). Além desse argumento da ordem, tal escolha do escritor insere na narrativa uma marca da realidade, pois o Mosteiro de São Bento, fundado em 1590, é um dos mais tradicionais do Rio de Janeiro.

Também em Os Irmãos Karamázov, o diabo enaltece a ordem que observa entre os homens: “Aqui entre vós, tudo é especificado, aqui há fórmula, aqui há geometria, ao passo que entre nós tudo são equações indefinidas!” (Dostoiévski,

\footnotetext{
${ }^{2}$ Conforme a Regra do Glorioso Patriarca São Bento, com tradução e notas de Dom João Evangelista Enout, da Ordem de São Bento (RJ). O documento está disponível na internet: http://www.osb.org.br. Acesso em setembro de 2010.
} 
2008, p. 827), estas talvez equivalentes à "desorganização", ao "reinado casual e adventício" (Assis, 1994, p. 3) que o diabo machadiano tenta superar. No romance russo, a congregação religiosa alvo de menções irônicas é a dos jesuítas, igualmente caracterizada pela rígida disciplina de obediência e aceitação dos preceitos da Igreja Católica. O irreverente demônio criado por Dostoiévski diverte-se ao narrar a relação dos padres jesuítas com os fiéis: "Quanto a esses confessionários de jesuítas, são na verdade minha mais encantadora distração nos momentos tristes da vida" (Dostoiévski, 2008, p. 837).

Essa aspiração à ordem é paradoxal no "espírito de negação", conforme o próprio demônio se autodefine. Afinal, a ordem e a disciplina exigidas para a prática religiosa impõem limites claros visando a reprimir transgressões, sufocar desejos e manter sob controle paixões individuais a fim de preservar a coesão do grupo perante o poder divino. Tais parâmetros acabam por permear toda a sociedade e contribuir para a manutenção de padrões de convivência comunitária aceitáveis. Já o demoníaco é justamente aquilo que vem para desagregar, negar e desestabilizar a ordem vigente por meio da transgressão. "Se a figura de Deus se forma em torno da ideia de absoluto, a do diabo é aquela que desagrega, que provoca o esfacelamento e a oposição. É a própria ideia de fragmento, de parte cindida.” Por outro lado, “o espírito que nega é o que brinca, o que oferece o inesperado, o que pode promover o jogo irônico" (Moura, 2008, p. 136 e 138).

A escassa boa vontade demonstrada por Deus no capítulo II do conto "A Igreja do Diabo" está distante da que se observa no "Prólogo no Céu", no qual Deus chega a ser condescendente com o demônio ao lhe destacar a função de não permitir que o ser humano "soçobre em integral repouso" (Goethe, 2004, p. 57). No episódio machadiano, o Criador dispensa conhecer os resultados do empreendimento do demônio - que mesmo assim externa a sua admiração por Deus, a exemplo do que ocorre no Fausto - e praticamente o enxota do céu.

Tu és vulgar, que é o pior que pode acontecer a um espírito da tua espécie, replicou-lhe o Senhor. Tudo o que dizes ou digas está dito e redito pelos moralistas do mundo. É assunto gasto; e se não tens força, nem originalidade para renovar um assunto gasto, melhor é que te cales e te retires. (Assis, 1994) 
Curiosamente, termos semelhantes são utilizados por Ivan Karamázov para tentar se livrar do demônio que o assedia: “(...) não és capaz de me dizer nada de novo. (...) És tolo e vulgar" (Dostoiévski, 2008, p. 825).

A benevolência divina para com o diabo só ressurge no final da narração de Machado, quando "Deus ouviu-o com infinita complacência; não o interrompeu, não o repreendeu, não triunfou, sequer, daquela agonia satânica" (Assis, 1994, p. 7).

No aspecto paródico da narrativa de Machado de Assis, Magali Moura é muito feliz ao interpretar a conclusão do conto, em que se evidencia o jogo de contrários, confirmando a afirmação de Mefistófeles de ser ele o espírito que, ao querer o mal, gera o bem. Ficam também ali patentes as "contradições humanas", a eterna insatisfação, a busca ininterrupta de um sentido para a vida, a ponto de chegar ao nonsense:

A surpresa do leitor ao final do texto é alcançada pela maestria de Machado com a utilização do jogo irônico que subverte a ação e atribui ao próprio humano a categoria de "espírito de negação" antes atribuída ao Diabo. O ser humano é apresentado como um ser em eterno estado de negação e o Diabo, falho em sua intenção de promover o mal, acaba por criar o bem. O jogo promovido por Machado culmina na percepção da apresentação dos homens como os próprios seres diabólicos por estarem sempre em contradição, em estado de negação, o que acaba por provocar a alternância, o movimento incessante que mantém a própria vida. (Moura, 2008, p. 143)

Evidentemente, as duas narrativas, tanto a de Machado de Assis como a de Dostoiévski, estão impregnadas de vários elementos identificados com a carnavalização da literatura. Além da própria temática, que envolve a questão primordial do bem e do mal, do certo e do bom, de Deus e do diabo, os textos contêm a inversão de valores, a revogação das leis, a profanação de símbolos sagrados, os duplos, os contrários, a paródia e, especificamente na obra de Machado de Assis, a praça pública e o ritual de coroação e destronamento.

Todo esse material foi arrolado por Bakthin para desenvolver os conceitos de carnavalização da literatura. O teórico toma por base as Saturnais romanas, festas pagãs revestidas de caráter ritual, período em que os seres humanos podiam ver-se e se relacionar como iguais, aproximar-se e se misturar na praça pública, destronar o rei, parodiar o sagrado, enfim, destituir todo o poder e os valores constituídos, colocando no lugar o seu oposto. 
Formada ao longo de séculos, a linguagem romanesca incorporou esses fenômenos chegando à literatura carnavalizada, que é, por excelência, a expressão literária da modernidade, uma vez que comporta a multiplicidade de línguas, o dialogismo, a coexistência, no cerne do discurso, de muitas vozes e entonações, fazendo emergir a relativização de tudo, o movimento perene do ser humano incompleto em seu presente inacabado.

\section{Espírito de negação}

Em “A Igreja do Diabo", um trunfo apresentado pelo demônio para garantir o sucesso de sua empreitada é a unicidade da instituição, na qual, pensa ele precipitadamente, não há risco de ocorrerem cisões ou dissidências porque "há muitos modos de afirmar; há só um de negar tudo" (Assis, 1994, p. 2). Em seu diálogo com Deus, ele reforça essa posição: "Senhor, eu sou, como sabeis, o espírito que nega" (Assis, 1994, p. 4).

Também em Goethe e em Dostoiévski, o "espírito de negação" do demônio é ressaltado. Os três autores, no entanto, vão muito além de uma visão simplista e maniqueísta em que se opõem vida e morte, bem e mal.

Sou parte da Energia

Que sempre o Mal pretende e que o Bem sempre cria. (...)

O Gênio sou que sempre nega! (Goethe, 2007, p. 139)

Dostoiévski aproveita essa citação de Goethe para que o demônio, em seu diálogo com Ivan Karamázov, supere ainda mais as expectativas que convencionalmente lhe imputam e coloque em prática o "método" que adotou para confundir seu interlocutor com paradoxos e o jogo entre real e imaginário: "Mefistófeles, ao aparecer a Fausto, disse de si mesmo que desejava o mal, mas fazia apenas o bem. Ora, faça ele lá como quiser, mas eu sou o oposto total. Eu talvez seja a única pessoa em toda a natureza que ama a verdade e deseja sinceramente o bem" (Dostoiévski, 2008, p. 838).

Ele desempenha a função de duplo parodiador de Ivan, uma das características da literatura carnavalizada. "O diabo grita aos ouvidos de Ivan Karamázov as próprias palavras deste (...) repetindo com o tom de outro as palavras mais caras dele" (Bakhtin, 2010, p. 254). Para Bakhtin, o capítulo "O diabo. O pesadelo de Ivan Fiódorovitch" constitui-se em uma verdadeira menipeia, um dos gêneros do sério- 
cômico antigos incorporados à literatura moderna no processo de carnavalização. Em seu discurso, o diabo dostoievskiano fala do seu papel no mundo, da sua indispensável existência para que o sentido da vida não se perca.

Por uma missão primordial, que nunca consegui entender, fui destinado a "negar", (...) sem negação não haveria crítica, (...) Sem crítica, só haveria Hosana. Mas, para viver, só o Hosana não basta, é preciso que esse Hosana passe pelo crisol da dúvida, e assim sucessivamente. (...) eu, por exemplo, exijo simples e francamente a minha destruição. Não, vive, dizem, porque sem ti não haverá nada. Se tudo no mundo fosse sensato, nada aconteceria. Sem ti não haveria quaisquer acontecimentos, e é preciso que haja acontecimentos. E então trabalho a contragosto para que haja acontecimentos e crio o insensato cumprindo ordem. (...) Sem sofrimento, que prazer poderia haver em viver? - tudo se transformaria num infinito Te Deum: é uma coisa sagrada, porém meio chata. (Dostoiévski, 2008, p. 831)

Ainda de acordo com Bakhtin, "todos os símbolos carnavalescos incorporam a perspectiva de negação (morte) ou o contrário. O nascimento é prenhe de morte, a morte, de um novo nascimento" (Bakhtin, 2010, p. 142), e essa dinâmica favorece o processo de mudança e renovação.

Considerando os autores em estudo, cuja profundidade e abrangência das obras buscam desvendar a alma humana, a negação não se reveste de um caráter negativo monolítico, mas sim pendular, representa o questionamento, significa abrir a porta da dúvida para que o discernimento possa penetrar; é a inquietação fáustica que coloca o ser humano em movimento e promove a sua evolução; é rejeitar o pronto e acabado, o absoluto, relativizando a condição humana e a expondo em toda a sua precariedade. Por tudo isso, esse "espírito de negação" é indispensável à vida, porque é ele que impede a acomodação e impulsiona o ser humano a transgredir, pois, mesmo trilhando o caminho da dúvida e da negação, é por ele que chegará a alguma verdade, visto que esta também é vulnerável à mutabilidade dos tempos e à pluralidade de visões.

Assim considera Magali Moura:

Sendo parte do mal que se verte em bem, [o diabo] é uma personagem com caráter de esfinge que se põe diante de Fausto e acaba por ajudá-lo a encontrar o caminho que o leva finalmente a Deus. (...) Há uma inversão das ideias comuns e a admissão da valorização do que é tido como mal como parte necessária para o alcance do bem. (MOURA, 2008, p. 138 e 140) 
Se, por um lado, o "espírito de negação", questionador e crítico, é motor de transformação, por outro, alimenta a eterna insatisfação humana, consistindo em fonte de tormentos e infelicidade. A solução apresentada pelo diabo dostoievskiano para sair desse dilema é mais uma imagem mordaz e paródica:

Meu sonho é encarnar - mas que seja definitivamente, irreversivelmente - em alguma mulher de comerciante, gorda, que pese umas sete arrobas, e acreditar em tudo que ela acredita. Meu ideal é entrar na igreja e acender uma vela de todo coração, juro! Então seria o fim de meus sofrimentos. (Dostoiévski, 2008, p. 827)

\section{Golpes de eloquência}

O espírito de negação é o que leva os demônios representados em "A Igreja do Diabo" e em Os Irmãos Karamázov a proferir seus discursos com uma retórica toda própria, repleta de ironia e sarcasmo, que põe a nu a hipocrisia e as contradições humanas. Esse discurso-paródia desvenda o interdito e a força da natureza, o lado selvagem do humano, que, a despeito de todos os esforços exigidos pelo sagrado, teima em emergir.

Os dois diabos apresentam-se queixosos pelo desprezo humano, mas assumem sua condição em busca de mudar a imagem que lhes foi imputada, e salientam o relevante papel dos instintos na natureza humana, dos quais são os defensores na Terra. "Amo sinceramente os homens - oh, tenho sido alvo de muita calúnia!" (Dostoiévski, 2008, p. 827).

Em verdade, estás furioso comigo porque não te apareci assim numa auréola rubra, "entre ribombos e brilhos", de asas chamuscadas, mas nestes trajes tão modestos. (...) Ainda há pouco, quando vinha para cá, pensei por brincadeira em me apresentar como um conselheiro de Estado aposentado, que servira no Cáucaso, com a estrela do Leão e do Sol no fraque, mas me deu muito medo de que me espancasses só pela ousadia de ter posto no fraque o Leão e o Sol, e não ter posto pelo menos a Estrela Polar ou Sirius. (Dostoiévski, 2008, p. 838)

Confessava que era o Diabo; mas confessava-o para retificar a noção que os homens tinham dele e desmentir as histórias que a seu respeito contavam as velhas beatas.

- Sim, sou o Diabo, repetia ele; não o Diabo das noites sulfúreas, dos contos soníferos, terror das crianças, mas o Diabo verdadeiro e único, o próprio gênio da natureza, a que se deu aquele nome para arredá-lo 
do coração dos homens. Vede-me gentil e airoso. Sou o vosso verdadeiro pai. Vamos lá: tomai daquele nome, inventado para meu desdouro, fazei dele um troféu e um lábaro, e eu vos darei tudo, tudo, tudo, tudo, tudo, tudo... (Assis, 1994; grifo nosso)

Uma lourinha, uma normanda de uns vinte anos, procura um velho padre. Beleza, corpo, natureza - de dar água na boca. (...) aquilo era o clamor da própria natureza, se quiseres, era melhor do que a própria inocência! No mesmo instante liberei o pecado para ela e já ia dando as costas para sair, mas fui imediatamente forçado a voltar: ouço pelo buraquinho do confessionário o padre marcar um encontro com ela para a noite, e o velho era uma rocha, mas caiu num piscar de olhos! A natureza, a verdade da natureza se sobrepôs! (Dostoiévski, 2008, p. 837; grifos nossos)

"Ele prometia aos seus discípulos e fiéis as delícias da terra, todas as glórias, os deleites mais íntimos" (Assis, 1994, p. 4). "A única hipótese em que ele permitia amar ao próximo era quando se tratasse de amar as damas alheias, porque essa espécie de amor tinha a particularidade de não ser outra coisa mais do que o amor do indivíduo a si mesmo" (ASSIS, 1994, p. 6).

O demônio caracterizado por Dostoiévski com maestria desenvolve sua argumentação alternando comentários jocosos e considerações filosóficas a respeito de Deus e da fé - as grandes questões de Ivan Karamázov. Segundo Bakhtin, em Dostoiévski a "fé vive em plena fronteira com o ateísmo, fita-o e o compreende, enquanto o ateísmo vive na fronteira com a fé e a compreende" (Bakhtin, 2010, p. 204). Já na representação de Machado de Assis, o diabo adota o tom pedagógico para realizar o seu intento de constituir uma igreja hegemônica.

A doutrina era a que podia ser na boca de um espírito de negação. Isso quanto à substância, porque, acerca da forma, era umas vezes sutil, outras cínica e deslavada. (...)

As turbas corriam atrás dele entusiasmadas. O Diabo incutia-lhes, a grandes golpes de eloqüência, toda a nova ordem de coisas, trocando a noção delas, fazendo amar as perversas e detestar as sãs. (Assis, 1994, p. 5)

No capítulo III do conto - "A boa nova aos homens" -, Machado de Assis lança mão de um recurso antigo e muito utilizado pela Igreja Católica, pela literatura e pelas artes em geral ao longo de séculos, que é a difundida noção dos Sete Pecados Capitais, merecedores de condenação e penitência. A origem desse conceito remonta ao poema épico Psychomachia, datado do século IV e cuja autoria é atribuída a 
Prudêncio. Cada um dos pecados capitais tem, em contrapartida, uma das Sete Virtudes, que, uma vez praticadas com contumácia, protegeriam os seres humanos de caírem em tentação. $\mathrm{Na}$ ordem em que aparecem citados no texto, são estes os pecados capitais e as respectivas virtudes correspondentes:

\begin{tabular}{|l|l|}
\hline Soberba & Humildade \\
\hline Luxúria & Castidade \\
\hline Preguiça & Diligência \\
\hline Avareza & Generosidade \\
\hline Ira & Paciência \\
\hline Gula & Temperança \\
\hline Inveja & Caridade \\
\hline
\end{tabular}

Todo o trabalho do diabo machadiano partiu da constatação, feita depois de séculos de observação, de que "as virtudes, filhas do céu, são em grande número comparáveis a rainhas, cujo manto de veludo rematasse em franjas de algodão. Ora, eu proponho-me a puxá-las por essa franja, e trazê-las todas para minha igreja; atrás delas virão as de seda pura (...)" (Assis, 1994, p. 3). Assim, o discurso proferido pelo diabo se constrói invertendo os paradigmas das virtudes por meio de uma lógica própria e de sofismas elaborados, denotando um narrador/autor sofisticado, cujo domínio da linguagem leva a um resultado de fina ironia e crítica.

Nessa "vida às avessas", nesse "mundo invertido" (Bakhtin, 2010, p. 140) está presente a cosmovisão carnavalesca, conforme proposta por Bakhtin, e ainda pode-se identificar o que o teórico denominou "palavra autoritária" e "palavra interiormente persuasiva". A primeira é o dogma religioso, monolítico, acabado, imposto e inquestionável, e a segunda, o discurso ideológico do demônio, que, por outro prisma, abre uma nova perspectiva de interpretação ao dialogar com questões muito humanas - o desejo, a inveja, a vaidade. Entretanto, e isso é posto por Machado de Assis de maneira muito original, essa palavra interiormente persuasiva se propõe a substituir o antigo dogma, ocupando o seu lugar de autoridade, e talvez aí esteja a sua vulnerabilidade diante da natureza humana - inconstante, mutável, contestadora e crítica, ou ainda, para nos aproximarmos da colocação de Magali Moura, uma índole "negadora".

Uma a uma, as virtudes são puxadas pelo demônio por suas franjas de algodão. Elevadas são as considerações às virtudes "naturais e legítimas" em que se 
transformaram os sete pecados capitais. Com relação à gula e à luxúria, por exemplo, "quem negaria que era muito melhor sentir na boca e no ventre os bons manjares, em grande cópia, do que os maus bocados, ou a saliva do jejum?" (Assis, 1994, p. 5). Ele expõe a hipocrisia e o fingimento do homem em sociedade e como, sob o véu protetor do ritual, abriga e dá vazão aos seus instintos e sentimentos mesquinhos, o que o predispõe a aderir, com facilidade, à nova religião proposta pelo demônio.

- Olhai bem. Muitos corpos que ajoelham aos vossos pés, nos templos do mundo, trazem as anquinhas da sala e da rua, os rostos tingem-se do mesmo pó, os lenços cheiram aos mesmos cheiros, as pupilas centelham de curiosidade e devoção entre o livro santo e o bigode do pecado. Vede o ardor, - a indiferença, ao menos, - com que esse cavalheiro põe em letras públicas os benefícios que liberalmente espalha, - ou sejam roupas ou botas, ou moedas, ou quaisquer dessas matérias necessárias à vida... Mas não quero parecer que me detenho em coisas miúdas; não falo, por exemplo, da placidez com que este juiz de irmandade, nas procissões, carrega piedosamente ao peito o vosso amor e uma comenda... Vou a negócios mais altos... (Assis, 1994, p. 4)

A título de contar como pegou um resfriado, também o demônio dostoievskiano relembra sua participação em uma circunstância prosaica semelhante. "Na ocasião eu tinha pressa de chegar a uma reunião diplomática em casa de uma senhora da alta sociedade de São Petersburgo, que aspirava a ser ministra" (Dostoiévski, 2008, p. 828).

Ambos os autores valem-se de diversas referências ao cotidiano de suas respectivas realidades, tais como as menções a Liev Tolstói, Gatzuk e ao extrato de malte de Hoff, em Dostoiévski; a Homero, Rabelais, Galiani e ao poema Hissope, em Machado de Assis. Tal recurso fornece às narrativas a necessária sustentação de verossimilhança, suficiente para alcançar algum grau de identificação do leitor, mantendo-o conectado ao enredo e às ideias veiculadas.

Retomando os argumentos do diabo machadiano, para não nos determos em cada um deles, destacaremos o conceito de "venalidade", que aqui está relacionado ao pacto fáustico, ou seja, ao ato de vender a alma ao diabo.

A venalidade, disse o Diabo, era o exercício de um direito superior a todos os direitos. Se tu podes vender a tua casa, o teu boi, o teu sapato, o teu chapéu, coisas que são tuas por uma razão jurídica e legal, mas que, em todo caso, estão fora de ti, como é que não podes vender a tua opinião, o teu voto, a tua palavra, a tua fé, coisas que são mais do que 
tuas, porque são a tua própria consciência, isto é, tu mesmo? Negá-lo é cair no absurdo e no contraditório. (Assis, 1994)

O séquito do diabo machadiano foi levado a praticar o mal e a desfrutar dos prazeres, tudo instituído e regulamentado, e assim o fez. Despiu o manto de veludo que ostentava, do qual arrastava franjas de algodão pelo chão, ficou nu, dando vazão aos seus instintos e perversidades. No entanto, mesmo sob a proteção do demônio e podendo viver nesse "estado de natureza", não se satisfez, negou o próprio "espírito de negação" e partiu para praticar o bem. Em uma e outra condição, não chegou ao absoluto. A explicação, no conto machadiano, vem do Criador, quase em consolo ao demônio mais uma vez vencido: "Que queres tu, meu pobre Diabo? As capas de algodão têm agora franjas de seda, como as de veludo tiveram franjas de algodão. Que queres tu? É a eterna contradição humana" (Assis, 1994, p. 7).

Sob o manto da "eterna contradição humana" estão as ambiguidades, a multiplicidade de consciências em diálogo, a inquietação e a constante insatisfação, a negação, o movimento pendular dos sentimentos humanos em relação a si e ao outro, a necessidade de transgressão, de morte para renascer, de renovação. Tudo o que é matéria da vida e não cabe nos limites restritos de uma doutrina.

A contradição humana é a propulsão à mudança. A aceitação dessa condição tão precária e ao mesmo tempo tão vigorosa abre as comportas da energia para a criação. Toda essa matéria da vida está presente nas obras estudadas. Se em Machado de Assis apresenta-se em tom mais leve, com fina ironia e crítica mordaz, e em Dostoiévski emerge do seu característico diálogo de consciências e do discurso ideológico aliados à paródia, em ambos germina a semente do velho Goethe, dos dilemas transcendentais do homem moderno e contemporâneo - a sua interioridade, os seus desejos interditos, o seu questionamento, a sua incompletude. Essa capacidade de representar a realidade além dos seus limites visíveis, embora sensíveis a todos os seres humanos, de tornar evidente o que é latente e transmutá-lo em linguagem faz desses escritores referências na arte e na vida.

\section{Referências bibliográficas}

Assis, J. M. Machado de. "A Igreja do Diabo". In: Histórias sem Data. Disponível em: http://machado.mec.gov.br/images/stories/pdf/contos/macn004.pdf. Texto-fonte: Assis, Machado de. Obra Completa. Rio de Janeiro: Nova Aguilar, 1994. Vol. II. Acesso em 14/7/2010. 
A Semana. Rio de Janeiro: W. M. Jackson Inc. Editores, 1946. $2^{\circ}$ vol., 263269.

Bakhtin, Mikhail. Problemas da Poética de Dostoiévski. Rio de Janeiro: Editora Forense Universitária, 2010a. Tradução de Paulo Bezerra.

Questões de Literatura e de Estética - A Teoria do Romance. São Paulo:

Hucitec Editora, 2010b. Tradução de Aurora Fornoni Bernardini e outros.

Bezerra, Paulo. "O Laboratório do Gênio". In: Dostoiévski, Fiódor M. O Duplo. Tradução de Paulo Bezerra. São Paulo: Editora 34, 2011, 237-248.

- "Mundos Desdobrados, Seres Duplicados". In: Caderno de Literatura e

Cultura Russa. São Paulo: Ateliê Editorial, 2008, 245-251.

Dostoiévski, Fiódor M. Os Irmãos Karamázov. São Paulo: Editora 34, 2008.

Tradução de Paulo Bezerra.

Goethe, J. W. von. Fausto - Uma tragédia (primeira parte). São Paulo: Editora 34, 2004. Tradução de Jenny Klabin Segall.

. Fausto - Uma tragédia (segunda parte). São Paulo: Editora 34, 2007.

Tradução de Jenny Klabin Segall.

Mazzari, Marcus V. Romance de Formação em Perspectiva Histórica: O Tambor de

Lata de Günter Grass. São Paulo: Ateliê Editoral, 1999.

Mosteiro de São Bento do Rio de Janeiro. Regra do Glorioso Patriarca São Bento.

Tradução e notas de Dom João Evangelista Enout, da Ordem de São Bento (RJ).

Disponível em: http://www.osb.org.br/mosteiro/pdf/Regra_do_glorioso_Patriarca_

Sao_Bento.pdf. Acesso em setembro de 2010.

Moura, Magali. “O Riso Diabólico em Machado e Goethe. Algumas Reflexões sobre a Luta do Mal contra o Bem”. In: Revista de Letras, vol. 48, n 2, 2008, 131-150.

Disponível em: http://seer.fclar.unesp.br/letras/article/view/1193. Acesso em setembro de 2010 .

Rouche, Michel. “Alta Idade Média Ocidental”. In: História da Vida Privada - Do Império Romano ao Ano Mil. São Paulo: Companhia das Letras, 2009. 